\title{
シミュレーションによる航路計画の研究 SIMULATION STUDY ON CHANNEL PLANNING
}

\section{1. 緒言}

われわれの社会は明らかに新しい段階に突入しつつあ る。スコット・グリアは「われわれの持つ担保のす心゙て が周囲の都市的世界の財産として吸いとられている1」 と述べている。そしてこの状況は, わが国における計画 視座の変更を引き起こし, 拠点主義的な全国総合開発計 画から，全国的なネットワーク構造の確立をめざす新全 国総合開発計画への変遷をもたらした。これは社会体系 における量的変化に伴ってじゃっ起された価值体系の変 化であり, 社会の基盤的なシステムが, 量的扡大の結果, 他のシステムとより強い関連性のもとに置かれ, 相互に 補完しあって機能する時代に至ったことを意味する。こ のことは社会の各計画化において, 計画間, あるいはシ ステム間の位階性を無視した個別的計画手法の非有効性 の宣言である。ティンバーゲンは, プロジェクトの評価 という問題において, 補完的 (complementaly) プロジ ェクトの概念 ${ }^{2)}$ を用いているが，これはプロジェクト間 の位階性の一つの概念であり, 計画間の位階性の概念に まで抎張されねばならない。われわれは, ある計画(上 位計画）を実現するために実現されていなければならな いサブシステムの計画を補完的計画ということにする。 この場合, 補完的計画の条件の一つとして, 上位計画よ り要請された諸要求事項がその計画で満足されているこ との必要性がある。しかしそのシステムの開発に伴う物 理的, 技術的, 資金的，あるいは時間的制約等の強さに よっては,それらを完全には満足させえない場合があ る。したがって上位計画はその補完的システムの分析結 果を, その補完性の強さに応じてフィードバック情報と して受けとらねばならない。

すなわち, 補完的プロジェクトの計画理論は, これら

* 正会員 京都大学助手 工学部土木工学科

** 正会員 (株)日建設計
木 俣 昇*.石 崎 肇 士** By Noboru Kimata and Hajime Ishizaki

制約と要求事項の満足との関係を操作的に解析すること によって, 上位計画へのフィードバック量を求めること であるといえよう。補完的計画の手法としては，その元 来の機能よりみてシステム論的計画理論がその有效性を 十分に発揮することが期待される。

本研究は, このような観点より港湾計画, あるいは臨 海部を中心とする地域計画の補完的計画として, 近年そ の重要性を増してきている航路の整備計画のためのシス テム開発を目的とするものである。

わが国は瀬戸内海を始め東京湾, 大阪湾, 伊勢湾等重 要地点に狭水路を有しており, 開発規模の拡大に伴って 急激に航路交通量が上位計画の制約として作用するに至 った。特に瀬戸内海地域は, 水深 $-11 \mathrm{~m}$, 幅員 $500 \mathrm{~m}$ の早鞆瀬戸を初め, 水樑 $-10 \mathrm{~m}$, 幅員 $400 \mathrm{~m}$ の来島中 水道 (北航のみ), 水哚 $-11 \mathrm{~m}$, 幅員 $700 \mathrm{~m}$ の備讃瀬 戸北水道等の日本有数の狭水路を入出口に有しており, ポートアイランド, 大阪港海上都市構想等を初めとする 瀬戸内海沿岸地域の大規模開発計画は, その補完的なシ ステムである航路の交通容量の面より検討を加えておく 必要があるだろう。

われわれが対象とする船舶交通に関して, 二つの大き な特徵を指摘することができる。その一つは, その大き な慣性力に起因する船舶運動上の特性, たとえば前進惰 力の制御の困難性に伴ら操船における行動選択の順序 性, 緊急停止に伴う旋回現象による安全確保の困難性等 である。他の一つは, 通航船舶が 100 トン以下の小型船 から 10000 トン以上の大型船にわたっており, その交 通流は速度, 大きさの両者とも分散が非常に大きな混合 流であるということである。

われわれは, 船舶運動の特性を定式化し, 直線の主航 路に横断航路が直角に交差する理想化された航路におけ る通航船舶のシミュレーションモデルを構成し, その混 合流を解析することによりシステム論的航路計画の展開 の第一段階としたい。 


\section{2. 航路における船舶交通の特徴}

船舶は, 航路の形式, 海象, 気象扝よび船舶の輻輳度 を考虑して, 前後 $1 \sim 3 \mathrm{~km}$ のを安全確認領域内の他船 舶との安全を確保するに必要な行動系列を, 自船舶の操 船性能に規定された範囲内で決定することによって航路 を通航している。船舶の行動は，一般にその大きな慣性 カやプロペラ推力の左右不平衡性, 潮流等非線形的な力 関係に起因する種々の特殊性を持つが，モデル的には， 他船舶との衝突回避の状況を想定し, 前方向, 横方向の 閉塞領域 ${ }^{33.7)}$ が侵害されない行動の中から操船上の安定 性を考慮し，通航所要時間を比較することによって決定 される。

横方向の閉塞領域とは, 二船がすれちがう時,「二船 間の海水の運動によって相互に吸引力が作用し接触する 危険を回避するのに必要な船舶間の横方向距離」であり， その大きさは一般に船舶の垂線間長 $L$ ，あるいは $1.5 L$ 程度とされている ${ }^{3)}$ 。一方, 前方向の閉塞領域は, 状況 に応じて種々想定される。たとえば，二船舶の他に障害 物が少なく，十分な水域がある場合は，主機反転，35度 転舵で惰行する直進距離とすることができる。しかし, 水域が狭く左右に船首が振れては危険な場合は，主機反 転を用いることができず8)，極微速後進，錨をもって停 船できる距離となる。実際に航路で観測される前方向閉 塞領域はだいたいこの間の值である。

藤井らは，(1)先行船の運動状態の変化を認めるまで の時間と，(2)適切な避航動作が行なわれるまでの時間 をもとに，船舶の垂線間長 $L$ を用いて， $8 L, 3 L$ の半 だ円形をその船舶の閉塞領域として推定している゙”。一 方, 京浜運河, 浦賀水道での船舶間の距離の実測調查 ${ }^{7}$ では, 船長 $10 \sim 50 \mathrm{~m}$ の船舶の閉塞領域は, 横方 向に 50 120 m, 前方向 $150 \sim 200 \mathrm{~m}$ ，船長 70 130 m の船 舶については, 横方向 250 350 m, 前方向 500 1000 m となっている。

もちろん, 船速, 潮流, 視程, 輻輳度, さらに操船者 の心理的要因によって, これら閉塞領域の值は変化する し, 先行船が後続船に転針や減速を通知し, 後続船がそ れを確認するようにすれば，大幅に減少するとされてい る。閉塞領域の概念は船舶交通の定式化において重要な ものであるが，上でみたようにその大きさは種々想定さ れる。われわれは，この值を操作可能なようにモデルに 組み入れることにより,この問題を解決する必要がある。

他の船舶交通の特徵として, 慣性力の制御困難性に起 因する (i ) 自由走航, (ii) 旋回, (iii) 減速, (iv) 機関 停止および（v)反転といら行動選択の順序性の傾向を あげることができる。これは船舶の航跡調查によって推
測されることである。運輸省が実施した調査 ${ }^{4), 5)}$ によれ ば, 船舶は衝突回避行動として減速や機関停止, 反転を 必要とする以前に前方船を旋回で回避し, 自由走航を追 求していることがわかる。また潮流や推進機関等, 非線 形的な力を受ける操船において迅速性のみならず力学的 安定性を重視するのは当然であろう。実際に観測される 船舶の動態は, 潮流, 視程, 航路の屈曲, 陸岸の影響等 が複雑に関連し, さらに操船者の心理的要因が加わった 結果であることは明らかである。

本研究は航路計画のための一種の情報システム ${ }^{19)}$ の作 成を目的としており，現段階で明らかにされている資料 をもとに船舶の動態のシミュレーションモデルを作成 し，それにシステム分析の手法を適用することによって 高次の計画情報を求めることを試みた。われわれは以下 の分析で船舶交通の基本的構造として，一定距離の安全 確認領域, 他船との安全確認のための前方向, 横方向の 閉塞領域，および上述の 5 種類の行動間の選択順序を設 定し，船舶交通の定式化を試みた。

\section{3. 船舶の行動系列決定システムの概要}

本節では前節で設定した基本的構造のもとで，船舶の 動態をシミュレートするための基本的事項である船舶の 行動系列の決定方式について概説する。

前節で設定したように船舶は航行時にはその内に含ま れる他船との安全を確認する安全確認領域をもってい る。本研究では, 航路をこの安全確認領域によって数ブ ロックに分割し, さらに船舶の占有水域を表現するため に船舶の垂線間長を基準にレーンに分割する。

すなわちモデル航路は 図一1 のようにブロック，レー ンに分割され，ブロックは一船ブロックと交差ブロック に区別される。

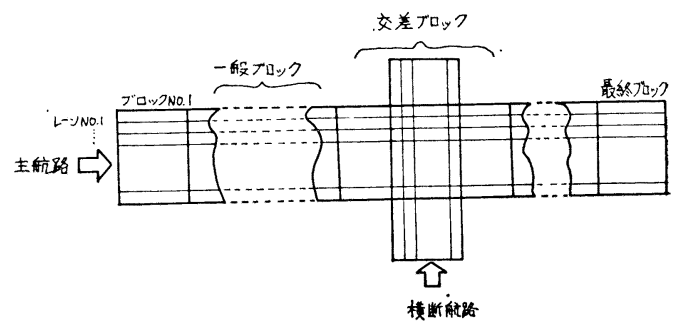

\section{図一1＼cjkstart航路のモデル図}

船舶の行動系列とは，第一ブロックにおける船舶到着 に始まり, 各ブロックの通航行動の系列の決定をへて, 最終ブロックの通航完了確認によって終了する一連の船 舶の採用行動の系列である。その概要は, 航路の入口の 第一ブロック，それに続く一般ブロック，および主航路 と横断航路が交差する交差ブロックに扔いて，次のよう 
に定式化される。

特に本研究では, 主航路に優先指定がない場合を取り 上げる。このような場合には海上衝突予防法によって, 他船を右舷にみる船舶が他船の進路を避けるものとされ ている。したがって図一1において主航路を通航する船 舶は左から右へ, 横断航路を通航する船舶は下から上へ 通航する場合を考察することになる。

\section{（1） 第一ブロックにおける船舶の発生}

船舶の航路への到着は, 第一ブロックでの船舶の発生 に対応する。船舶はある確率分布によって発生し, 第一 ブロックへの侵入の可, 不可を第一ブロック内の他船と の前方向, 横方向の閉塞領域によって検討することによ り，その船舶の侵入位置のレーン番号および船舶の大き さに応じた占有レーン数を指定する。

到着分布は一般的にはポアソン分布が経験的に設定さ れる ${ }^{3)}{ }^{97}$ が，各港湾と対象航路との位置関係によって異 なるため，ここでは任意分布を設定できるようにした。

\section{（2）ブロック内通航の安全の確認方式}

船舶の航路内航行の条件は, 次のようである。

(i ) 横方向の閉塞領域の確保

(ii） ブロック内およびブロック通過完了時点での前 方向の閉塞領域の確保

(iii）船舶はその動力機関の特性上非連続的な $80 \%$, $60 \%$ 二段階の減速速度を持つ。この範囲で他船 との安全を確保できない場合は機関停止，あるい は極微後進を必要とするが，この場合は操船性が 非常に低下するので異常として記録する。

（iv）船舶は後方の船舶との安全が保てる限り，前方 船を二船まで旋回で通航レーンを変更することに より回避することが許される。

（v）航行中後方より自船より速い船舶が航行してき た場合，自船が別に定める通航路移譲義務船の場 合には,その通航位置を開放しなければならない。 自船が何らかの理由で旋回できない場合はこの限 りではない。

これら 5 個の前提条件のもとでのブロック内通航の最 早の行動予定は, 図一2 の作業順序図で示されるように システム的に決定される。

\section{（3）ブロック通航完了の確認方式}

船舶はまずブロック侵入時に, 安全確認領域に対応す るブロック内の通航行動の予定表を図一2のシステムに したがって作成する。この予定行動は, その船舶の通航 完了時において次の二種類の確認を受け, 実行動とな る。

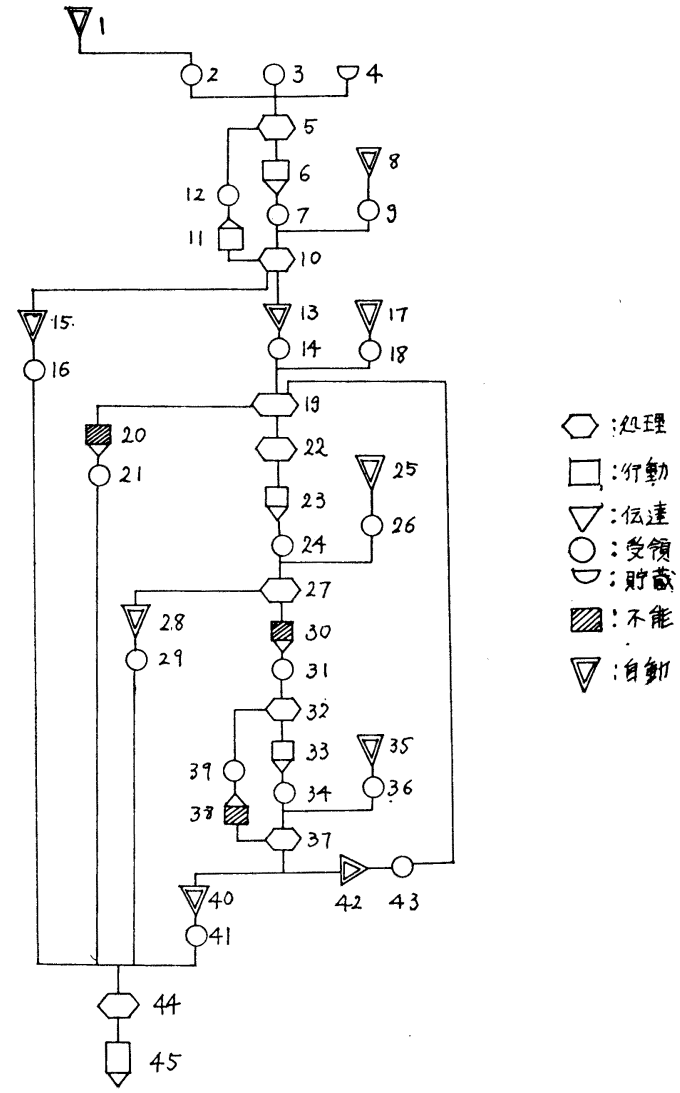

\begin{tabular}{|c|c|c|c|}
\hline 1,2 & 環境情報 & 27 & 安全か \\
\hline 3 & 自船の条件 & 28,29 & 航路変更した場合の適航 \\
\hline 4 & 航法に関するルール & & 状態 \\
\hline 5 & 通航速度のセット & 30,31 & 危 険 \\
\hline 6,7 & 航 行 & 32 & 減速速度セット \\
\hline , 9 & 他船情㪕 & 33,34 & 航 行 \\
\hline 10 & 安全か & 35,36 & 他船情報 \\
\hline 11,12 & 危 險 & 37 & 安全か \\
\hline 13,14 & 直進航行の検郡完了 & 38,39 & 危 険 \\
\hline 15,16 & $\begin{array}{l}\text { 直進航行の場合の通航状 } \\
\text { 態 }\end{array}$ & 40,41 & $\begin{array}{l}\text { 航路変更および減速した } \\
\text { 場合の通航状態 }\end{array}$ \\
\hline 17,18 & 航路状態情報 & 42,43 & 航路変更の 1 case 検討 \\
\hline 19 & 航路変更するか & & 終了 \\
\hline 20,21 & 航路変更不能 & 44 & 最早通過時刻をもつルー \\
\hline 22 & 航路位置は何処にするか & & 卜決定 \\
\hline 23 & 航 行 & 45 & 航 行 \\
\hline 25,26 & 他船情報 & & \\
\hline
\end{tabular}

図一2 ブロック内通路予定行動決定システム

（i）ブロック内通航中に, 前方船が減速によって自 船の閉塞領域を侵さなかったか。

(ii) ブロック通航完了時点において, 次ブロック内 に自船の閉塞領域を侵している船舶がいないか。 この二つの安全確認において不備が生じた場合は, ブ ロック内の通航予定行動を変更し再度安全確認を行な う。通航完了の確認は図一3 の作業順序図のようにシス テム化される。 


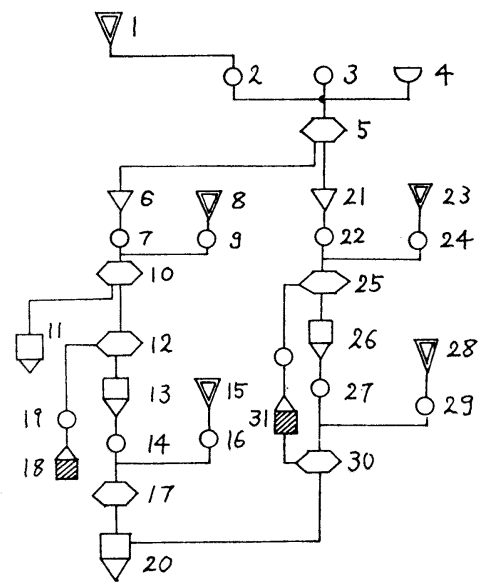

\begin{tabular}{|c|c|c|c|}
\hline, 2 & 環境, 同フロック内 & & 減 速 \\
\hline & 通航船舶状態の情報 & 13,14 & 航 行 \\
\hline 3 & 自船条件 & 15,16 & 他船情報 \\
\hline 4 & 航法のルール & 17 & 安全か \\
\hline 5 & 同フロック内で情報もれ & 18,19 & 危 険 \\
\hline & による他船との間に危険 & & 現ブロック通航やり直し \\
\hline 6,7 & $\begin{array}{l}\text { はなかったか } \\
\text { 通行可 }\end{array}$ & $\begin{array}{l}21,22 \\
23,24\end{array}$ & $\begin{array}{l}\text { 通行不能情報 } \\
\text { 他船情報 }\end{array}$ \\
\hline 8,9 & $\begin{array}{l}\text { 次プロック内通航船舶情 } \\
\text { 報 }\end{array}$ & $\begin{array}{l}25 \\
26,27\end{array}$ & $\begin{array}{ll}\text { 減 速 } \\
\text { 航行 }\end{array}$ \\
\hline 10 & $\begin{array}{l}\text { 次ブロック内通航船船に } \\
\text { 対して現ブロックを通過 }\end{array}$ & $\begin{array}{l}28,29 \\
30\end{array}$ & $\begin{array}{l}\text { 他船情報 } \\
\text { 安全か }\end{array}$ \\
\hline & $\begin{array}{l}\text { 完了して安全か } \\
\text { 通過完了 }\end{array}$ & 31,32 & 危 険 \\
\hline
\end{tabular}

図一3ブロック通過完了確認システム

\section{（4）交差航路における航行方式}

主航路に優先権が認められていない場合には，海上衝 突予防法が適用されるので, 航路横断船舶が著しく増加 するならば主航路の通航に支障をきたす。交差ブロック における主航路通航船舶の行動は次のような制約を受け る。

(i ) 別に定める横断船舶に対する安全確認領域内の 全船舶に対して, 交差完了するまで, 相互の閉塞 領域を確保する。

(ii) 主航路通航船舶は海上衝突予防法により右舷に 見る横断船舶の通航をさまたげてはならない。そ して横断船舶を回避する場合には，必ず横断船舶 の後方を通航しなければならない。

(iii) 船舶の減速は一般ブロックと同じである。

（iv） 主航路を通航中の他船との安全確認は一般ブロ ックの場合と同じである。

（v）横断船舶によって主航路が通航できない場合に は, 交差ブロック入口において, 通航可能となる まで待機しなければならない。一般に船舶は停船 状態においては不安定であるので, この場合も異 常事態として記録する。

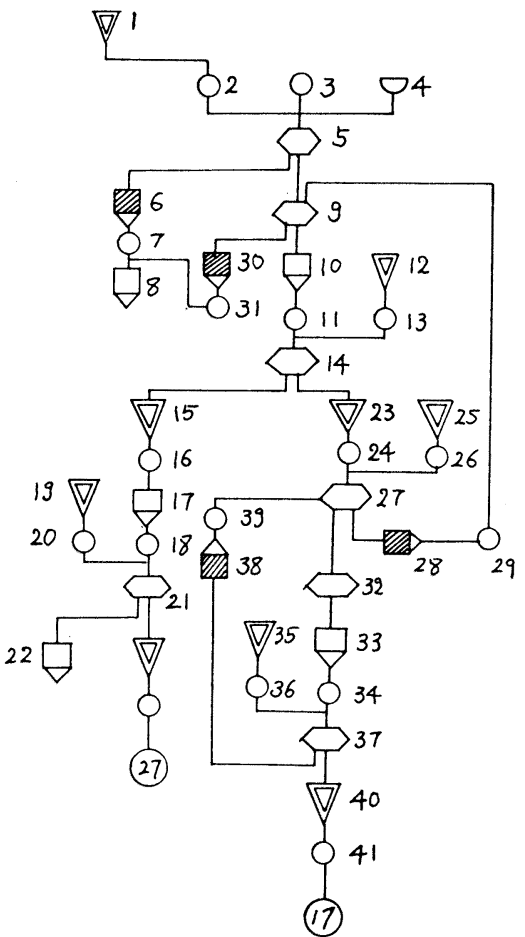

\begin{tabular}{|c|c|c|c|}
\hline 1,2 & $\begin{array}{l}\text { 環境情報むうよひ待機船情 } \\
\text { 報 }\end{array}$ & $\begin{array}{l}21 \\
22\end{array}$ & $\begin{array}{l}\text { 安全か } \\
\text { 通過予定決定 }\end{array}$ \\
\hline 3 & 自船の条件 & 23,24 & 航行不能 \\
\hline 4 & 航法のルール & 25,26 & 航路状態抢よび後力船情 \\
\hline 5 & 自船の通航路前方に待機 & & 報 \\
\hline & 船がいか & 27 & 航路変更できるか \\
\hline 6,7 & 行動不能 & 28,29 & 航路芠更不能 \\
\hline 8 & 待 機 & 30,31 & 減速不能 \\
\hline 9 & $\begin{array}{l}\text { 通航速度セット, 減速可 } \\
\text { 能か }\end{array}$ & $\begin{array}{l}32 \\
33,34\end{array}$ & $\begin{array}{l}\text { 航路位置選択 } \\
\text { 航行およびその情報 }\end{array}$ \\
\hline 10,11 & 航行およびその情報 & 35,36 & 横断船舶情報 \\
\hline 12,13 & 横断船船情報 & 37 & 安全小 \\
\hline 14 & 安全か & 38,39 & 航行不能 \\
\hline 15,16 & 安 全 & 40,41 & 横断船舶安全 \\
\hline 17,18 & 航行およびその情摯 & 42,43 & 前方船に対して危険 \\
\hline
\end{tabular}

19,20 前方船舶情報

図一4 交差ブロック通航予定行動決定システム

（vi） 交差ブロック入口で待機船がすでにいる場合， その待機位置が自船の閉塞領域を侵害するなら， 待機船が動き出すまで交差ブロックへの侵入は許 されない。

以上の制約の下で，交差ブロックでの主航路通航船舶 の行動決定は，作業順序図によって図一4のようにシス テム化される。

ここで, 通航路移譲義務船とは後続船の船速, 船型と の差がある一定值以上の場合の前方小型船を指すものと する。これは航路の通航規制の一種であり, 計画の手段 の一つとして政策的に決定されるものである。本研究で は, 通航船舶を船種, 船型の組み合せによってを 表一1 のようにランクに分けている。ここでは通航路移譲義務 
表一1 船舶統一ランク表

\begin{tabular}{|c|c|c|c|c|}
\hline$\underbrace{}_{\text {トン数 }}$ 船 種 & $\begin{array}{l}\text { 货 } \\
\text { 物 } \\
\text { 船 }\end{array}$ & $\begin{array}{l}\text { 夕 } \\
\text { 年 } \\
\text { 力 } \\
1\end{array}$ & $\begin{array}{ll}\text { フ } & \text { 各 } \\
\text { 工 } & \\
\text { リ } & \\
\text { I } & \text { 船 }\end{array}$ & $\begin{array}{l}\text { 機 } \\
\text { 帆 } \\
\text { 船 }\end{array}$ \\
\hline 500 以下 & 1 & 1 & 3 & 1 \\
\hline $500 \sim 1000$ & 2 & 2 & 4 & \\
\hline $1000 \sim 3000$ & 3 & 3 & 5 & \\
\hline $3000 \sim 6000$ & 4 & 4 & & \\
\hline $6000 \sim 10000$ & 5 & 5 & & \\
\hline $10000 \sim 40000$ & 6 & 6 & & \\
\hline 40000 以上 & & 7 & & \\
\hline
\end{tabular}

船は, ランク差が 2 以上の小型船とする。

また計算機によるシミュレーションモデルの作成で は, システムの全状態が定義されていることが重要であ り, 前述の (1) 〜 (4) の通航行動の定式化関する条件 設定には, 船舶交通の特徴の他にシステムの完全記述の 条件が加わっている。たとえば旋回, あるいは第一，第 二減速で前方船との安全が確保できない場合の追随や, 交差ブロックへの進入待機の状態は船舶の運動特性上, 不安定かつ危険であり, 実際の船舶交通に扔いては異常 事態であるが, 船舶数を増加させてシミュレーションを 行なえばこれらの事態は, システム内部ではある確率で 出現するものであり，十分考慮しておく必要がある。

本研究では, システムの状態の完全記述とプログラミ ングの容易さのため 図一2〜図一4 に示すような作業順 序図を採用した。

\section{4. 航路シミュレーションモデルの概要}

前述の 2., 3. 節の船舶交通の基本的構造をもとに, 本節では time-slicing と event-sequencing ${ }^{10)}$ の複合 形として, 理想化された航路における船舶通航のシミュ レーションモデルを構成する。本研究では，3．節で述 べたように図一1 のモデル航路を対象とする。この航路 の幅員, 全長は, レーン数, ブロック数によって表示さ れる。ここに, レーンの幅は, 船舶の垂線間長 $L$, ブ ロックの長さは, 安全確認領域の長さをもとに決定され る。本モデルではまず第一に, 航路の船舶の行動を決定 する安全確認領域に対応する各ブロックの各船舶の通航 行動によって「事象」を定義し, 第二に, ブロックの入 出口において最早行動船舶を探索し, time-slicing の間 隔を決定する。

本モデルは, 図一5 に示すように船舶のブロック内通 航行動の予定表作成部, 最早行動の探索部, 通航の安全 確認部, 予定行動の修正部, および異常事態の検出部と 各種の統計処理部で構成されている。

ここで, ブロック内通航行動の予定表の作成, 通航の 安全確認, 予定行動の修正は, おのおの前節で定式化さ れたものであり, 図一2, 図一3, および図一4をサブシ ステムとする。本モデルでは計算機の容量制限よりシス テムの状態が，十隻以上の待機船をもつことになれば,

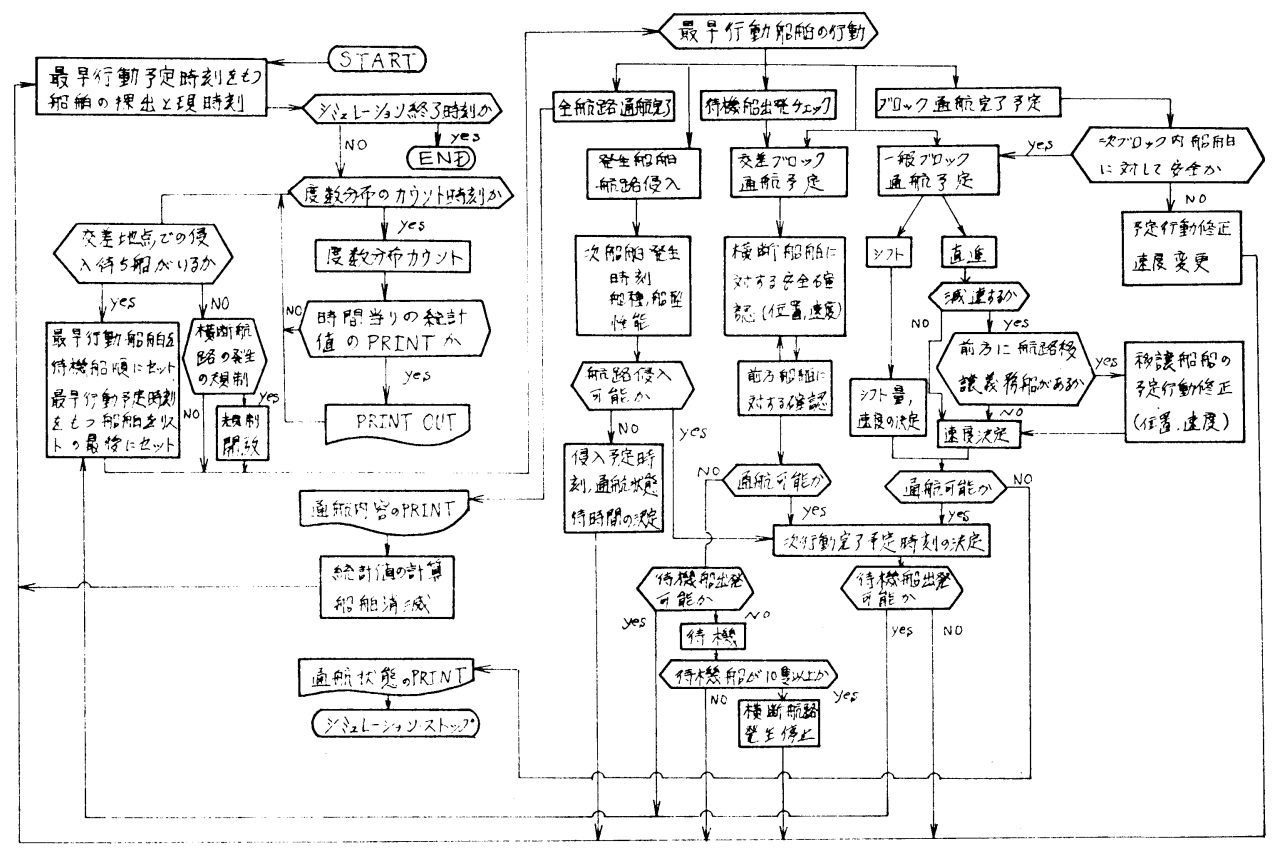

図一-5 航路シミュレーション・システムの概要 
一時横断船舶の発生を停止し, その旨を 記録し，計算を続行することにしてい る。本シミュレーションモデルの記憶容 量は, 約 3 万ワード, 内変数 1 万 4 千, プログラム 1 万 5 千であり, 10 時間分の シミュレーション時間は到着船舶数 $\lambda=$ 0.2 0.8 のとき, FACOM 230-60で 約 $3 \sim 4$ 分である。なお出力情報として は, 船舶の侵入待ち時間, ブロックごと の通航速度, 位置, 所要時間, 遅延時間, 行動内容 (一段, 二段減速, 異状減速, 旋回) および航路内航行船舶数である。

本モデルの特徵は, 船舶の垂線間長, 占有レーン数, 船速, 旋回性能; 安全確 認領域長; 前方向, 横方向閉塞領域長;

\section{および安全確認方式ですべてが決定され}

るといら点である。したがって, 他の要因はこれらの值 を媒介としてモデルに導入される。たとえば, 潮流は船 舶の対地速度, 前方向閉塞領域長, 安全確認領域長の変 化としてモデルに導入され, 操船者の心理的要因も同様 にこれらの值を確率変数として表現することによって, モデルに導入されることになる。

すなわち, 本モデルの信頼性は, 本モデルに直接表現 されていない航路システムの環境要素をいかにこれら内 部要素と関連づけ, 分析するかにかかっている。したが って本研究の分析においては, システム的方法の持つ操 作性を有効に用いる必要があるのである。

\section{5. 航路シミュレーションモデルの基礎的分析}

前述したようにこのシステムの出力の計画情報として の信頼性は, もちろん設定された基本的構造に全面的に 規定されるが, 環境要素と内部要素との関連の記述の信 頼性に依存する。したがってこの関連性を明らかにする と同時に, その不確実性を分類し ${ }^{12)}$, システムの操作性 を用いて，その定量的把握が試みられねばならない。

航路システムは, 図一6 のようなサブシステムに切断 される。前節では, その中で船舶技術条件, 航路条件, 通航規則を環境要因として, 船舶航行システムに対する シミュレーションによるモデル化が行なわれた。このモ

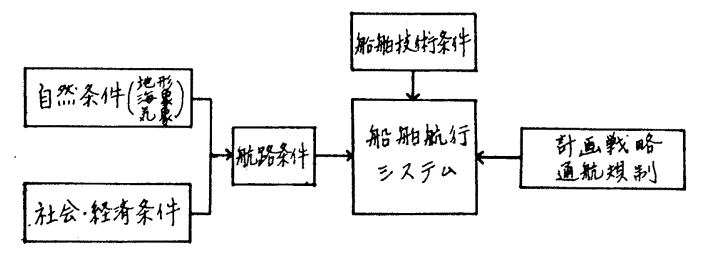

図一6 航路システムの概念図

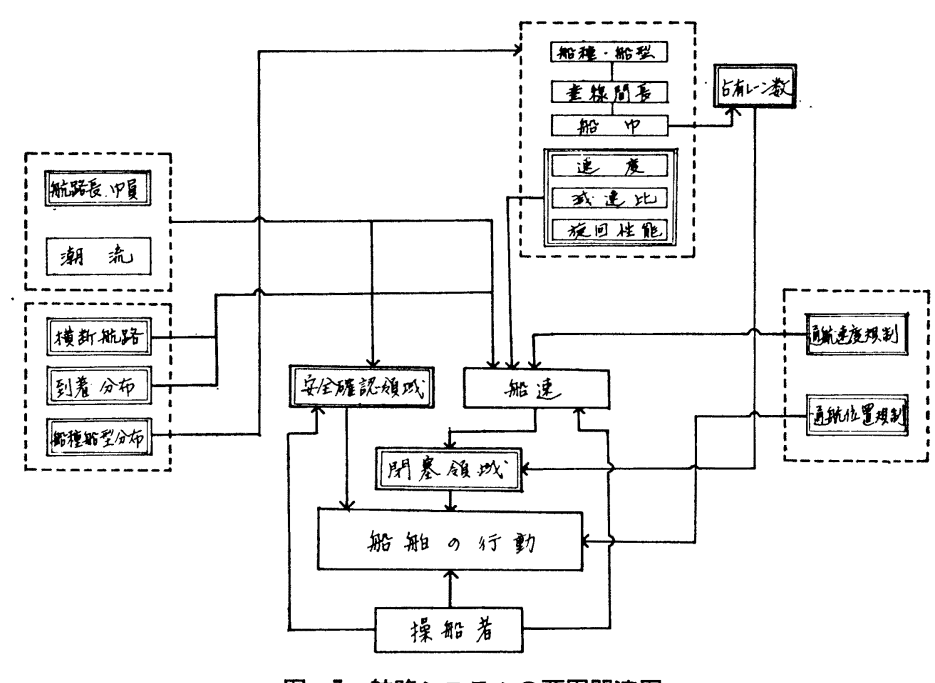

図一7 航路システムの要因関連図

デルに作用する環境要因を操作的に解析するため本シス テムを構成する要素を細分割し, その関連を求めれば, 図一7のように整理できる。

これらの要素は船舶およびその交通に関する要素, 人 的要素, 地理的航路条件の要素拉よび計画戦略の要素に 大別される。また一般システム理論 ${ }^{18)}$ でいう内的要素と システムの環境をなす環境要素といら分類を用いれば, 地理的航路条件の要素や人的要素は環境要素であり, 図 -7 の中の二重わくの要素は本システムで直接操作され る内的要素であるといえよう。

環境要素は二重わくの要素との関連においてシステム に作用するのであって, その影響を分析するためには環 境要素と二重わく要素との関連性の把握が重要となる。 しかし現段階においては, これらの関連性は少数のもの を除けば十分に調查, 解析されているとはいえない。そ れゆえに航路計画においては, システム分析の各種の手 法を適用することにより信頼性を向上するための努力が 必要となるのであって, われわれの提供するシステムも そのための一道具だてなのである。本節においては, 各 要素についての既存の調查結果を概説し, それをもとに 本システムの基礎的な分析として, システム構成要素の 要因分析と環境要素の分析を行なう。

\section{（1）船舶交通に関する調查結果の概説}

a) 船舶交通流に関しては到着分布, 船種 - 船型分布, 航路通航位置分布等関する多数の調查・報告 ${ }^{4}$, , 5),6), 9) がある。

船舶の到着分布は, 20 隻/時間以下の航行状態ではポ アソン分布が成立するとされている ${ }^{9}$ 。時間的な変動の パターンは一般に航路と港湾との位置関係により異な る。港湾周辺部においては荷役作業時間の影響を強く受 


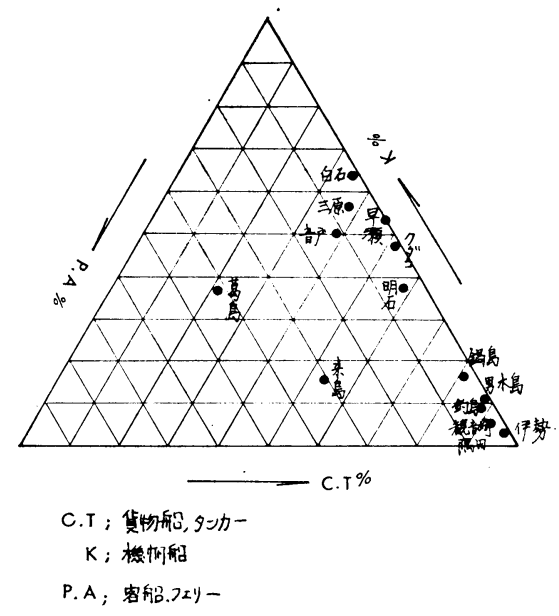

図一－航路別船種構成

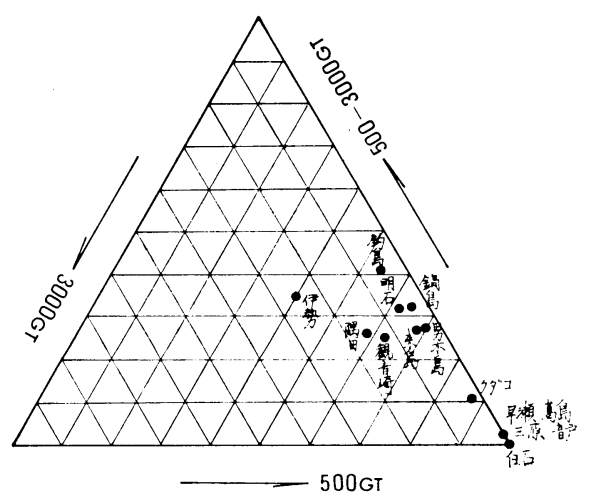

図一 9 航路別船型構成

け，変動は大きいが，遠くになるほど平滑化され時間的 変化が小さくなること文が報告されている。

船種, 船型構成は 図一8, 図一9 の上うになっており 主航路と副航路では大きく異なる。主航路は貨物船, 夕 ンカーが 90\% を占めるものと, 客船フェリーの比率が 相対的に多くなっているものとがある。一方, 副航路で は機帆船が $50 \%$ を占めることが大きな特徵である。

航路通航位置は, たとえば来島の中水道, 西水道では 潮流が南流の場合には, 中水道が南航船舶, 西水道が北 航船舶の推選航路となっており, 通航船舶はこの推選航 路にほぼ平行に航行していることが報告されている。

b）船舶の種々の特性は一般にその垂線間長 $L_{p p}$ と の関係で整理されている ${ }^{3), 13)}$ 。たとえば船舶の大きさ $(G T)$, 満載速力 (ノット), 旋回時間, 逆転停 止 距離 $(\mathrm{m})$ ，等はその対数を用いて，

$$
\log (G T)=2.82 \log (L)-2.06 \pm 0.06^{3)}
$$

のように推定されている。したがって船舶交通に関する 記述には, 船船の垂線間長が重要な媒介変数となる。

c）気象・海象と船舶動態との関係については,
(1) 潮流と船舶動態との関倸をみると, 前方向の船間 距離は, 順潮に比して逆潮の場合減少し, 横方向にはほ ぼ一定であるとされている。潮流と前方向船間距離との 関倸は,

$$
\begin{aligned}
& \left.l=8 L+650 \cdot(u / L)^{14}\right) \ldots . \\
& l=7 L+5 L_{0}\left(u \cdot L_{0} / V L\right)^{3)}
\end{aligned}
$$

の 2 種類の推定式が報告されている。ここに $L$ は船舶の 垂線間長 $\left(L_{p p}\right), u$ は潮流速 (ノット), $V$ は船速 (ノ ット), $L_{0}, V_{0}$ は定数である。潮流の解析には, その方 向性を考虑しなければならないが, 狭水路では, 主航路 の船舶は,同方向であり問題ない。横断船舶については, 横方向の偏位を加味しなければならないことになる。船 速については一般に操船性能が対水速度に関係するか ら, 潮流のある場合は, 船舶の大きさと潮流の流速の程 度にもよるが, 対地速度は潮流分だけ加減される。通航 位置に関しては $3000 G / T$ 以上では潮流の影響を受け ず, 航路内を通航するが, 小型船は特殊な航法でそれに 対処している

(2) 視程不良の原因は, 主として霧,スモッグであり, 沿岸地帯の工業化に伴って, 年々増加する傾向にある。 視程と船間距離, 船速, あるいは航行不能日数等につい ては十分の資料がない。

(3) 風波の影響は船舶の舵行現象として解析され, 調 查結果 ${ }^{15}$ によれば, 航路浮標が 3 カイリピッチとすれば 大体 $270 \mathrm{~m}$ 以内で修正されている。これは船舶の横方 向船間距離に関係し, それが $1.5 \mathrm{~L}$ 程度であれば, こ の影響は無視し得るといえる。

d）操船者の緊張については, 瀬戸内海の 6 力所の狭

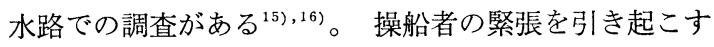
航路条件としては, 船舶の輻輳, 潮流, 水路幅, 湾曲見 とおし, 浅瀬, 航路標識の順となっている。しかし操船 者の緊張が操船にどのような変化として表われるのかに 関しては資料がない。

以上のように船舶交通に関する調査は, われわれが欲 する水準では不十分であり, 今後の調査に待た齐ばなら ない面が多い。

\section{(2) システム構成要素の要因分析}

計画システムの要素は計画手段である戦略集合と環境 集合に分類されるが17), 環境集合の要素は予測の対象と なるいくつかの状態と計測誤差による変動範囲を持つ。 この概念は実験計画法での制御要因と標示要因の概念を 用いて操作的定義に変換される。この場合, 標示要因に はいくつかの状態を持つ要素と, かなりの計測誤差が予 想される要素とが含まれることになる。

計画システムにおいて「結果の集合」といわれるもの は, システムの状態, あるいはそのスカラー的表現であ 
る特性值に対応する。特性值はシステムの状態を用いて 種々想定可能であり，そこに恣意性が入る余地がある。 補完的計画にあっては, 上位計画へのフィードバックと いら意味での合目的性が検討されねね゙ならない。システ ムによる「結果」の操作的定義は, 合目的性の客観的斉 合性を保障する一つの方法である。そしてシステム分析 は，「結果」とそれに対するシステムの要素の寄与率を 求め, 要素自身の信頼性とを対比することにより情報シ ステムとしての価値を明らかにする。

補完的計画である航路計画にあっては, 航路の交通容 量は重要な情報である。

交通容量の概念に関しては，まず 1950 年 Highway Capacity Manual において, 基本交通容量, 実用交通 容量, 可能交通容量の 3 種類の概念が明らかにされ, 次 いで 1966 年, 道路計画, あるいは既設道路の交通量の 評価のために「サービス水準」によるサービス交通容量 が定義された。航路の交通容量についても同様の概念を 導入することができる。その定義にもとゔけば，「サー ビス交通容量」の水準規定項目として, 相互に重複する が，(1）速度および旅行時間，(2) 交通の中断，または 障害, (3) 行動の自由性, (4) 安全性, (5) 運転の快適 性抢よび容易性，(6) 経済性の 6 項目をあげることがで きる。

船舶交通に関して上述の項目を検討すれば，船舶の運 動特性上, 第 2 項目の交通の中断または障害は, 他の項 目を全面的に規定するクリティカルなものといえる。

船舶交通に打ける船舶の停止は非常に危険なものとさ れ, 異常事態である。計画時点において, システムの異 常事態の発生確率を予測しておくことは非常に重要であ るが, 補完的なシステムである航路の計画にあっては, 異常事態の発生確率は小さな值に保れたている必要があ る。われわれはこのような考えのもとに，航路システム の定常的な状態での挙動を解析対象とする。

船舶の遅れは航路通航中旋回や減速を必要とする場合 に発生し, これは行動の自由性, 安全性, 快適性, 容易 性を低下させる。もちろん（1），(6) の項目とも直接関 係する。そこで，われわれはシステムの状態を記述する 特性值として, 期待通航所要時間からの遅れを採用する ことにする。ここで, 期待通航所要時間とは, 船舶が巡 航速度で航路全長を自由走航するに要する時間と定義す る。

システムの状態を規定する要素としては, 表一2 に示 すものを次のような理由で選択した。

a) 制御要因

船舶交通の特徵の一つとして, 航路通航船舶の船種, 船型扔よび船速ともその分散が大きい混合流であること をあげることができる。したがって補完的な航路計画に
表一2 要因と水準

\begin{tabular}{|c|c|c|}
\hline 因 & 水隼 & $\nu \check{~} ル$ 内容 \\
\hline \multirow{2}{*}{ A. 船型構成 } & 1 & 備讃瀬戸の西行観測データ \\
\hline & 2 & 水準 1 の大型船舶を 1.5 倍 \\
\hline \multirow{4}{*}{ B. 船舶発生パターン } & 1 & ピーク数 1 , ピーク率 $3 / 4$ \\
\hline & 2 & ピーク数 1, ピーク率 $1 / 2$ \\
\hline & 3 & ピーク数 1 , ピーク率 $1 / 4$ \\
\hline & 4 & ピーク数 0 \\
\hline \multirow{2}{*}{ C. 安全確認領域 } & 1 & $2000 \mathrm{~m}$ \\
\hline & 2 & $2500 \mathrm{~m}$ \\
\hline \multirow{2}{*}{$\begin{array}{l}\text { D. 減速による最小船間距離 } \\
\text { の補正率 }\end{array}$} & 1 & $95 \%, 75 \%, 60 \%$ \\
\hline & 2 & $95 \%, 80 \%, 70 \%$ \\
\hline \multirow{2}{*}{ E. 最小船間距離 } & 1 & 量線間長 $(L) \times 8.4$ \\
\hline & 2 & $L \times 8.4 \times 0.8$ \\
\hline \multirow{2}{*}{ F. 航路規制 } & 1 & 有り \\
\hline & 2 & 無し \\
\hline \multirow{2}{*}{ H. 占有レーン数 } & 1 & $L \times 1.5$ \\
\hline & 2 & $L \times 1.0$ \\
\hline \multirow{2}{*}{ I . 船速規制 } & 1 & 無し \\
\hline & 2 & 有り \\
\hline \multirow{2}{*}{ J. シフト所要時閻 } & 1 & 挍回䚶験の観測データ \\
\hline & 2 & $J_{1} \times 1.2$ \\
\hline
\end{tabular}

表一3 船 種 構 成

\begin{tabular}{l|c|c|c|c|c|c}
\hline 船 & 種 & 貨物船 & タンカー & 客 船 & フェリー & 機帆船 \\
\hline 登 & 主 航 路 & 0.50 & 0.20 & 0.05 & - & 0.25 \\
\cline { 2 - 7 } \\
\cline { 2 - 7 } & 横断航路 & 0.06 & 0.40 & 0.03 & 0.80 & 0.07 \\
\hline
\end{tabular}

おける容量を増大させる有効な計画手段の一つとして, 航路通航船舶に関する速度，通航位置の規制を考える。

船舶の速度規制としては, 航路通航船舶の最高速度を 10ノットとする。これは瀬戸内海航路の現状に近い水準 である。

通航位置規制としては，500 トン以下の小型船の通航 位置を航路中心より外側半分の水深の浅い所のみに規制 する。これは航路の拡張にともなら浚渫の経済性という 観点からみても妥当なものであろう。

b）標示要因

船舶の到着パターンは, 航路と港湾との位置関倸によ り異なる航路に固有の要因である。ここでは, ピーク率 との関係で 4 種類の水準を設定した。船型構成は主航路 と副航路では当然異なる。さらに将来の造船技術の革新 による大型化も予想される。ここでは現状の值と大型化 の一例として, 現状の大型船比率を 50\% 増した水準を 設定した。

他の要因は統計的誤差の影響による変動に関する標示 要因と考えられ, その変動範囲を水隻 1 , 水準 2 として 


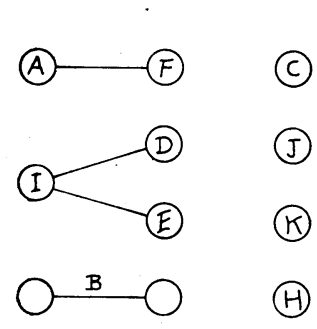

図-10 直交表 $L_{16}^{15}$ 線点図 による割付け
要因名

船艘生パーンB

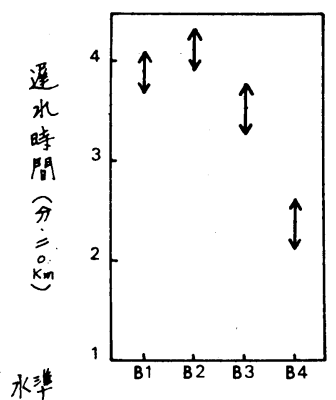

通航位显賛制F

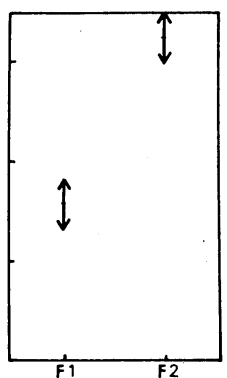

図一11 航路システムの要因効果図
占有レーン数 $\mathrm{H}$

通航速度规制1
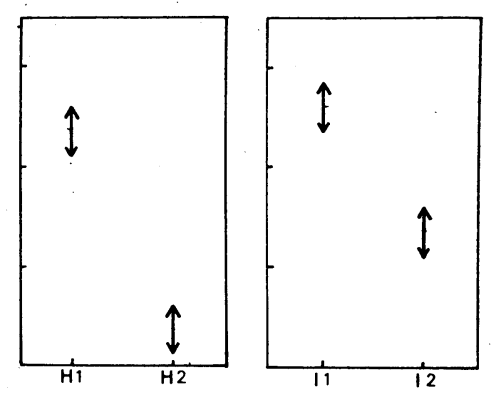

取ることにした。たとえば横方向閉塞領域を指定する占 有レーン数は, $L$ と $1.5 L$ の説があり, 本分析では水準 1 として $1.5 L$, 水準 2 として $L$ を取った。

表一2 の要因を直交表 $L_{16}^{15}$ の 線点図により, 図一10 のように割り付け, FACOM 230-60 により実験を実行 し, 分散分析表一4 を得た。表一 4 に示す寄与率より, 次のようなことが指摘できる。ここでは, 航路幅員は $600 \mathrm{~m}$ とした。

当然の結果ではあるが, 占有レーン数 $H$ が一番支配 的であり，その寄与率は約 $57 \%$ である。図一11 の要因 効果図をみると, この要因が $H_{1}=1.5 L$ より $H_{2}=L$ に変化することにより, システムの特性值である遅れ時 間は 3.4 分より 1.4 分になり, 約 2.5 倍の変化をするこ とがわかる。このことは図一7の要因間の関連図と合わ せて考えれば, 直接的には横方向の閉塞領域が, そして 船種, 船型構成も間接的にではあるが, システムを規定 する重要な要素であるといえよう。

他の本システムの標示要因は, いずれもその寄与率が 10\% 以下であり, その設定の差異による影響は少なく, 一応安定したシステムであるといえる。しかしその中で 図一11 に示したように，船舶の発生パターンは水準 2

\section{表-4 分散分析表}

\begin{tabular}{c|c|c|c|c|c}
\hline 要 因 & 自由度 & \multicolumn{1}{|c|}{$S S$} & \multicolumn{1}{c|}{$m S$} & \multicolumn{1}{c|}{$F$} & $\rho(\%)$ \\
\hline $\mathrm{A}$ & 1 & 0.0751 & 0.0751 & - & 0.03 \\
$\mathrm{~B}$ & 3 & 6.6415 & 2.2138 & 51.85 & 5.16 \\
$\mathrm{C}$ & 1 & 0.6627 & 0.6627 & 15.52 & 0.49 \\
$\mathrm{D}$ & 1 & 0.3332 & 0.3332 & 7.80 & 0.23 \\
$\mathrm{E}$ & 1 & 3.1108 & 3.1108 & 72.85 & 2.43 \\
$\mathrm{~F}$ & 1 & 1.3400 & 1.3400 & 265.57 & 8.95 \\
$\mathrm{~A} \times \mathrm{F}$ & 1 & 0.0119 & 0.0119 & - & - \\
$\mathrm{H}$ & 1 & 71.6672 & 71.6672 & 1678.39 & 56.73 \\
$\mathrm{I}$ & 1 & 20.1651 & 20.1651 & 472.25 & 15.94 \\
$\mathrm{~J}$ & 1 & 2.1581 & 2.1581 & 50.54 & 1.68 \\
$\mathrm{~K}$ & 1 & 0.0501 & 0.0501 & - & 0.48 \\
$\mathrm{I} \times \mathrm{E}$ & 1 & 0.0337 & 0.0337 & - & - \\
$\mathrm{I} \times \mathrm{D}$ & 1 & 9.9949 & 9.9949 & 234.07 & 7.88 \\
\hline $\mathrm{e}$ & 4 & 0.1708 & 0.0427 & & \\
\hline $\mathrm{ST}$ & & 126.244 & & & 100.00 \\
\hline
\end{tabular}

で特性值が最大值を持ち，水準 4 で最小值を持つ要因で あることは注目に值する。これは波動性が交通流に大き な影響を与えることを示している。

航路への船舶到着パターンはその航路の独自の特性で あり,一般に航路の交通容量は, 日当りのものと時間当 りのものとの間に線型的な関係が成立しなくなる。この ことは計画段階において，この要因を標示因子とするか どらかの十分な吟味が必要であることを意味する。

制御要因である通航位置規制 F および速度規制 I の寄 与率は，おのおの約 $9 \% ， 16 \%$ である。これは占有レ ーン数に次ぐものである。

このことより航路の浚渫・拡張と同様, 上位の計画構 想を実現するための計画化の有効な手段として, これら の規制を考えることが重要である。われわれは後の分析 において再度この問題を取り上げ，より具体的な規制に ついて検討を加えることにする。

\section{（3） システムの環境要素の分析}

航路計画システムは 4 節で設定されたモデルに陽表的 には含まれない要素を多数持つ。その一つとして潮流は 船舶交通にかなりの影響を与えるものと考えられる。潮 流は図一7の要因間の関連より, 船舶の速度と前方向閉 塞領域の変化としてモデルに導入される。

一般に船舶の操船性能は対水速度に関係しており, 船 舶の大きさと潮流の流速の程度にもよるが, 船速は潮流 速分だけ加減される。潮流のある場合の前方向閉塞領域 としては, 前述の調查結果にしたがい式 (3) の関係式 を採用した。

他の要因としては主航路を横断する船舶数と航路通航 位置規制を取りあげた。これは前述の（2）の分析結果 に基づき, 航路通航位置規制のより具体的分析を行なら ためである。

ここでは次のような水準の規制を取り上げた。 水準 1 ; 規制なし

水準 2 ; 速度に着目し，低速船である機帆船を航路外 
側 $200 \mathrm{~m} \mathrm{K，ランク} 3$ 以上の高速船を航路 内側 $400 \mathrm{~m}$ に規制し，混合流を分離した。 ただしフェリー，客船のランク 2 も高速船に 含まれる。

水準 3 ; 船舶の大きさに着目し，フェリ一，客船を除 くランク 1 の小型船を航路外側 $200 \mathrm{~m}$, ラン ク 4 以上の大型船（ランク 3 のフェリー，客 船を含む）を航路内側 $400 \mathrm{~m}$ に規制する。 次に横断船舶数は, 主航路に優先権の指定がない場合, その増加が主航路の機能停止の事態を引き起こすと予測 されるために取りあげた。

しかし，本分析では潮流および航路通航規制の効果を 主とする。したがって横断船舶の水準は，主航路が正常 に機能しうる程度のものを想定した。

以上 3 要因と水準を整理すると表一 5 となる。

表一5 要因と水準

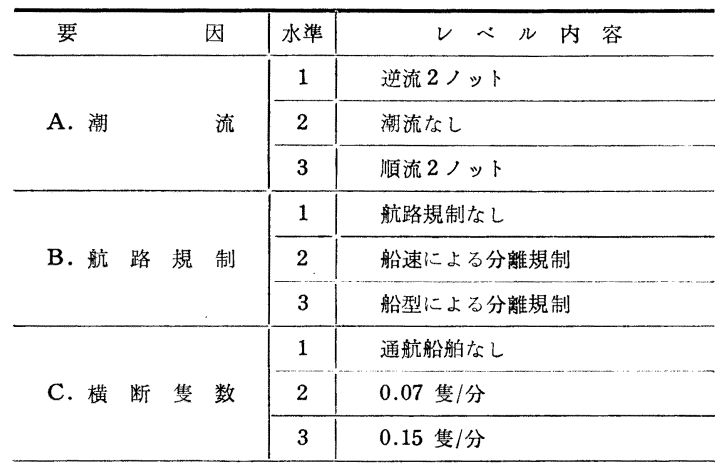

実験は FACOM 230-60 を用い，直交表 $L_{9}^{4}$ による 表一6 の割付け表に従って実施し，9 個の資料を得た。

実験は $\lambda$ の各水準で十時間のシミュレーションを行な

表一6 要因割付け表

\begin{tabular}{lr|l|l|l|l|l|l|l|l|l}
\hline 要 & 因 & 1 & 2 & 3 & 4 & 5 & 6 & 7 & 8 & 9 \\
\hline 潮 流 & 1 & 1 & 1 & 2 & 2 & 2 & 3 & 3 & 3 \\
位置規制 & 1 & 2 & 3 & 1 & 2 & 3 & 1 & 2 & 3 \\
横断隻数 & 1 & 2 & 3 & 2 & 3 & 1 & 3 & 1 & 2 \\
言 & 差 & 1 & 2 & 3 & 3 & 1 & 2 & 2 & 3 & 1 \\
\hline
\end{tabular}

要因名潮流A

水泟

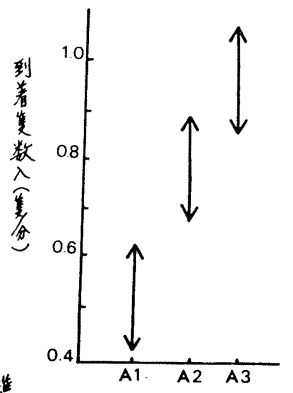

い, 時間当りの影響船舶比率を求め, その平均值が $80 \%$ となる $\lambda$ を決定する。次にこの $\lambda$ を到着率として，その 時の旋回回数, 減速回数の平均值を求めた。

ここに影響船舶比率とは, 通航完了船舶数に対する旋 回，減速を行なった船舶数の比率である。

表一7 はシミュレーションで求められた影響船舶が $80 \%$ となる到着率 $\lambda$ を特性值とする分散分析表である。

表-7 分 散分析表

\begin{tabular}{c|c|c|c|c|c}
\hline 要 因 & 自由度 & $S S$ & $m S$ & $F$ & $\rho(\%)$ \\
\hline $\mathrm{A}$ & 2 & 0.307 & 0.153 & 65.4 & 57.53 \\
$\mathrm{~B}$ & 2 & 0.193 & 0.096 & 41.15 & 35.86 \\
$\mathrm{C}$ & 2 & 0.021 & 0.010 & 4.38 & 3.02 \\
$\mathrm{E}$ & 2 & 0.005 & 0.002 & 1.00 & - \\
$\boldsymbol{e}$ & 0 & 0 & 0 & & $(3.59)$ \\
\hline $\mathrm{ST}$ & & 0.524 & & & 100.00 \\
\hline 譟 差 & 2 & 0.005 & 0.002 & & \\
\hline * 到着隻数 $\lambda$ 特性値とする。 & &
\end{tabular}

この表より，横断船舶 $C$ の寄与率をみれば $3 \%$ であ り，一応われわれが想定したようにその影響があまりな い状態にあることが確認できる。しかし，その効果の量 は小さいといえども, 図一12 の要因効果図より, この 要因の水準の増大にともなって, 特性值が容量減少の方 向に変化していることより，この要因の重要性が推測さ れる。われわれは，この横断船舶の影響については次節 で改めて考察を加えることにする。

環境要素である潮流 $A$ は (II) の分析結果と要因関連 図とからも推测されるように $57 \%$ という大きな寄与率 をもつ。大きな混合流である船舶交通流においては速度 差および前方閉塞領域長の分散が大きな影響力をもつ。

潮流は, 式（3）でモデルに導入される。この場合, 速度は潮流 $u$ の正, 負に応じて, 右あるいは左に $|u|$ だ け移動するだけであり，分散は変化しない。

しかし, 閉塞領域は $u / L$ の項のため分散が変化する。 $L$ がある值以上では潮流の影響は小さいが， $L$ が小さい 小型船では影響が表われ，したがって分布の下方が $u$ の 正負により左右に移動する。

通航规制B

横断隻数 C
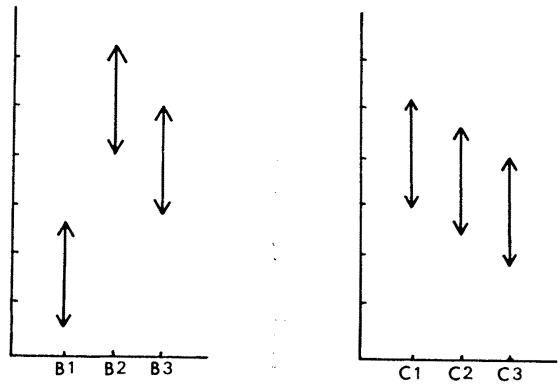
図一12 の要因効果図における順潮, 逆潮の 関係は上 述の理由によるものである。すなわち逆潮では閉塞領域 の分散が大きくなり, 影響船舶が増大する結果である。

船舶交通においては, ある範囲では旋回と減速は補完 的な関係にある。

航路通航位置規制は旋回範囲を制限するものである。 表一7 の分散分析表によれば航路通航位置規制 $B$ の寄与 率は $36 \%$ であり，その効果は図一12 に示されている。

これより規制による旋回制限にともなう減速の増大は 規制による混合流の分離の効果により, あまり大きくな らないことがわかる。これは船速を要因とする規制であ る水準 2 と船舶の大きさを基準とする水準 3 を比較すれ ばより明らかである。すなわち 図一13 において水準 2

要因名

潮流 $A$

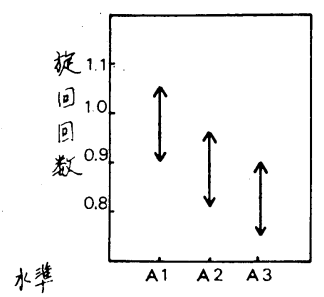

要因名

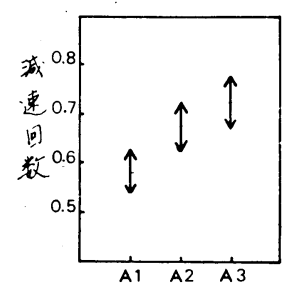

图一13 旋回, 減速回数に対する要因奻果図

が旋回, 減速回数についても水準 3 を上まわり，入で与 えられる容量を増大させている。これは単位, 速度とも に大きな分散をもつ船舶混合流においては, 速度による 分離が有効であることを示している。ただ船舶は, 前述 したように，垂線間長と船速が単調な関数関倸にあるか ら, 速度による分離は, 船型の分離をも含んでいること になる。

\section{6. 二, 三の数值実験について}

われわれは, 本システムを用いて, 二, 三の数值実験 を実施した。

\section{（1）航路交通容量の推定}

われわれは航路交通容量の外的基準として，(1) シス テムの状態ベクトルが，大きく変化する点，(2) 影響船
比率が $80 \%$ となる点および，(3) 時間当りの到着船舶 隻数と通航完了隻数にある程度差が生じる点を用いて相 互の容量の比較を行ない, 航路の交通容量の定義に関す る二, 三の検討を行なった。

本分析では, 航路幅 $600 \mathrm{~m}$ の直線の主航路に幅員 700 $\mathrm{m}$ の横断航路が直角に交差しているモデル航路を対象と する。

標示因子として, 横断船舶数は 5. (3) の分析の水 準 2 と 3 の中間值で， かつ現在の瀬戸内海航路の $50 \%$ 増の 6 隻/時間, 主航路の船種, 船型構成は, 備讃瀬戸 の現状值である 5.（2）の分析での水準 $A_{1}$ を想定し た。到着パターンは, 簡単のためピークなしの水準 $B_{4}$ を採用する。

システムの状態ベクトルは, 減速回数, 旋回数, 遅延 時間, 侵入待ち時間, および異常減速ブロック数の 5 個 の值をその要素とする。

到着隻数 $\lambda$ (隻/分)を 0.1 きざみで増加させ，おの おののレベルで 10 時間のシミュレーションを実施し, 上述の 5 個のシステム状態ベクトルの構成要素との関係 をおのおの求め, 図一14を得た。

同様にして求めた $\lambda$ と影響船舶比率, 通過完了隻数と の関係は 図一15, 図一16 に示すようになった。

（1）の外的基準に対しては，図一14 の各グラフは $=0.6$ 以上でその特性值が急増することが観察されるこ とより，その容量は 36 42 (隻/時間) 程度であるとみ ることができる。同様に（2）に対しては，39〜45（隻/ 時間), (3) に対しては, 36〜 42 (隻/時間) という值に なり, いずれにしてもこの場合の航路の時間当りの交通 容量は, 40隻/時間 前後と考えられる。

システムの状態ベクトルの各要素は, サービス水準規 定項目に対している。たとえば，(1)，(6) の項目は， 遅延時間, 侵入待ち時間の関数であり, (2)〜 (5) は減速 回数, 旋回数, 侵入待ち時間, および異常減速ブロック 数の関数となる。

サービス水準に関する外的基準は明確な操作的定義を もたない。われわれの分析は, システムの状態ベクトル により，これに対する一つの操作的定義を与える試みで ある。

それに対して，(2)，（3）の外的基準はより一層明確 なスカラー量で定義されており, その水準を指定するこ とにより，容量が確定する。しかし，いずれにしても最 終的な容量の確定には, 恣意的な側面が残されている。 分析結果によれば, これらの外的基準は, システムの状 態ベクトルの微係数最大, 影響船舶比率 $80 \%$ ，および 入力, 出力の乘離が $20 \%$ といら水準で同一の容量を与 えている。

これら恣意性を含む外的基準に対して, 操作的分析と 

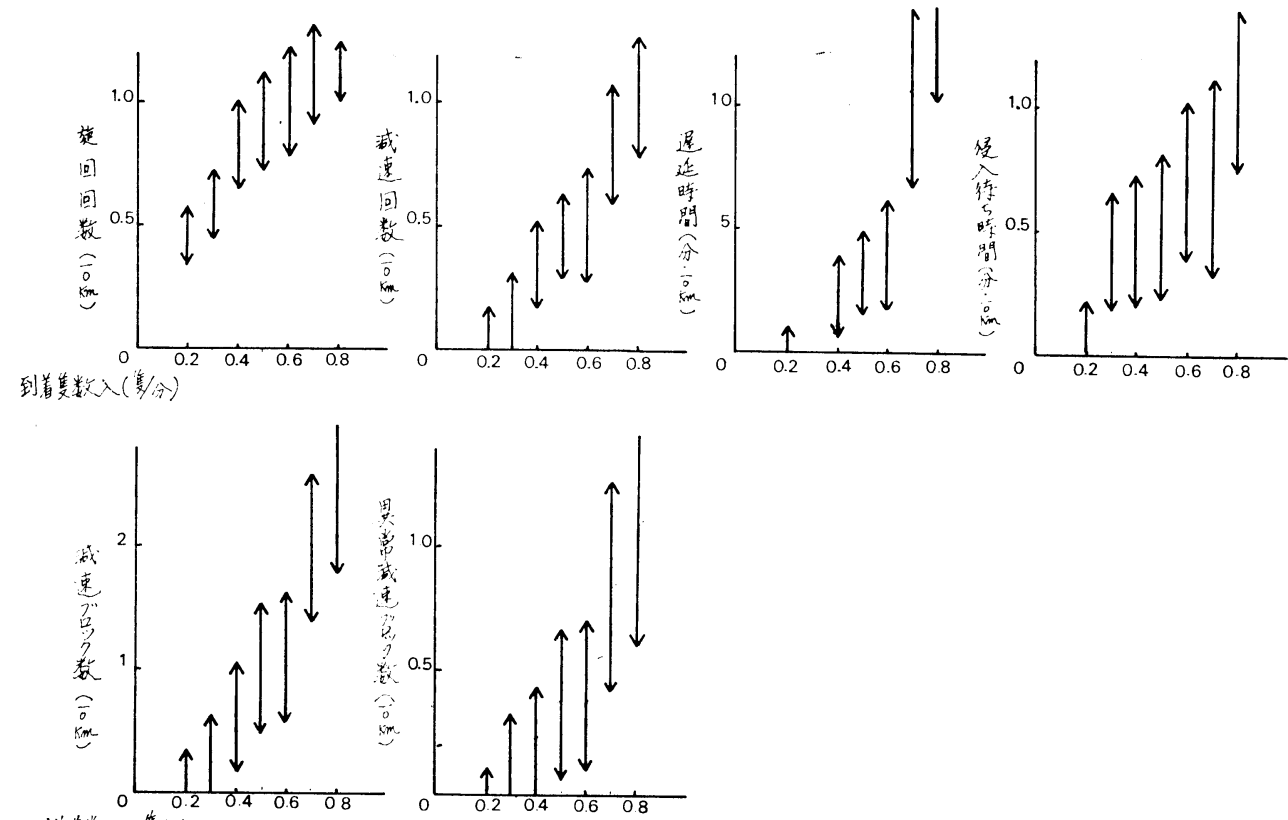

到着基数入(隻/分)

図一14 システムの状態ベクトルの変化

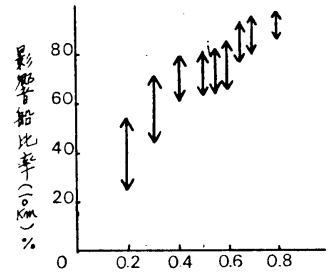

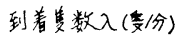

図一15 影響船比率

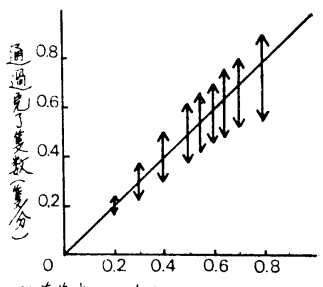

到着算数入(旁/分)

図一16 通過完了隻数と到着隻数

同時に経験的妥当性が十分に検討されることが必要であ ろう。

\section{（2）船舶交通流における群の発生}

これらグラフでのもう一つの特徵は, スの増加に伴う 分散の増大である。

これは低速の小型船舶に大型船が追随した場合, 船舶 交通流の密度分布に粗, 密が発生する結果である。その
状況は, 図一17 のシステム状態の出力図において, 明 確に観察される。

図一17 はランク 7 の船舶 281 の前方に, ランク 1 の 低速の小型船があり, 横方向閉塞領域が確保できないた めに，追越ができず，No. 281 の大型タンカーの後方に 群が発生した状況の出力である。

No. 281 の大型タンカーは，まず No. 279 の低速の 機帆船に追随し，さらに 9 ブロックでさらに低速の No. 268 の機帆船に追つき, No. 279 の機帆船は, それを追 越せるが，No. 281 のタンカーは横方向閉塞領域が確保 できないため，これに追随することになっている。

群の規模は,ブロック番号が進むにしたがって増大し， 13 ブロックでは, 20 隻程の船舶が前方向閉塞領域を減 速にともない $35 \%$ 亿減じ ${ }^{3)}$, 異常減速で追随している。

この群の発生は, 明確な車線の概念をもつ道路交通と 非常に異なる所である。また, 統計処理の時間間隔の取 り方により, 群の影響が表われ, 分散が異なることにな り，この決定が重要な問題となる。

\section{（3）横断船舶の影響の分析}

前節の (2) の分析でも指摘したように, 平面交差であ る航路では, 横断船舶の増大は主航路の機能低下, ひい ては機能停止を引き起こすことが予想される。

瀬戸内海航路においては, 神戸, 大阪港を目的港, あ るいは出発港とする主航路に, 中国一四国間の日発定期 船, フェリー, および客船の航路が交差しており, その 


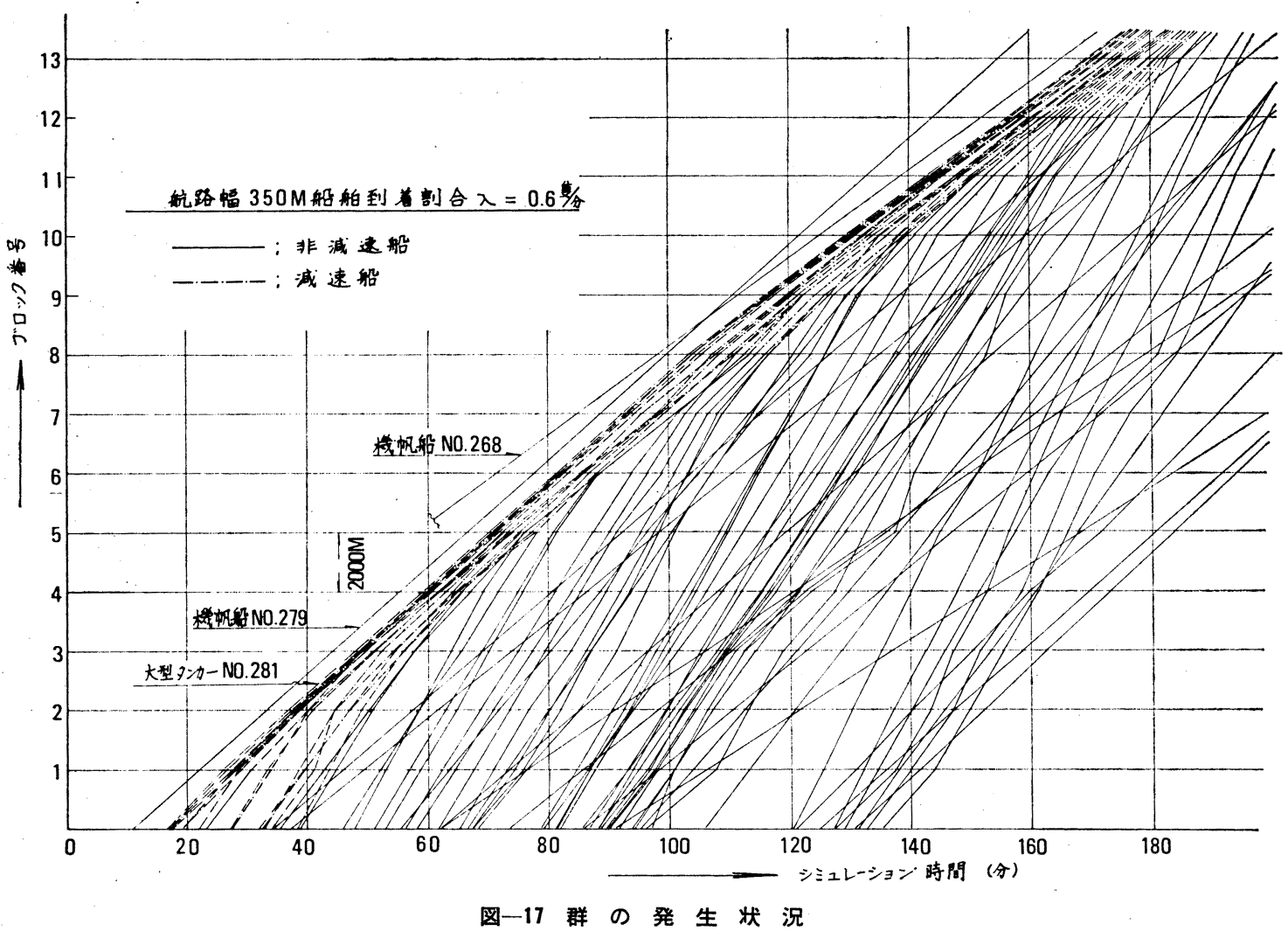

需要は, 主航路はもちろん横断航路においてもますます 増大する傾向にある。

本研究では, 現状の約 2 倍の 24 隻/時間の主航路交通 流の場合について, 横断船舶の影響を分析する。ここで 取り上げた時間当り 24 隻の航通量は, その船種, 船型 構成にもよるが, (I )の分析結果により, 現在の瀬戸内 海航路の容量以内にあると考えられるものである。

主航路の通過完了船舶数と横断船舶数との関係は, シ ミュレーション結果より 図一18 となる。横断船舶数が

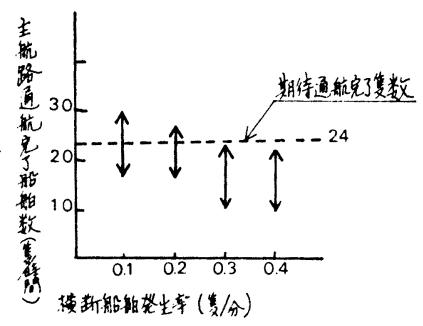

図-18 横断船舶の影望

0.1 (隻/分) の場合は, 主航路への到着隻数 24 (隻/時 間) と通過完了船舶数は一致しており，その影響はない。 しかしそれが 0.2 (隻/分) になると通過完了隻数が,
22 (隻/時間) となり, 横断船の影響があらわれる。0.3 （隻/分）ではシミュレーションシステムの待機船規約 による横断船舶の到着停止が, $2 \sim 3$ 分程度発生し, 0.4 (隻/分) ではそれは 10 12 分程度のものが 3 回発生す る。すなわち, 主航路交通量が 24 (隻/時間) 程度の場 合は, 横断航路の容量は $\lambda=0.2$ すなわち $9 \sim 12$ (隻/時 間）程度となる。

現状の瀬戸内海航路では, 横断船舶は平均 5 (隻/時 間) 程度である。これはピーク率を考虑すれば，航路交 通容量の限界に近いものであると想像される。

いま，海上交通の現状をみれば，臨海部の開発に伴い 増加の一途をたどっている。

特にポートアイランドの建設, 大阪湾および瀬戸内海 沿岸地域の大規模プロジェクトの進展に伴って, そこで の交通量は, 飛躍的に増大することが予想される。した がって, これら増大する船舶交通に対して十分な航路容 量がフィジカル (physical) に獲得できるかどらかが大 きな問題となってくる。このため,これら開発構想は, その補完的システムである航路の交通容量といら新たな 観点から再検討を加えることの必要性のあることを指摘 することができるであろう。 


\section{7. 結言}

航路は，港湾計画,地域計画の補完的システムであり， その計画にはシステム論的計画理論が実効的である。

本研究で開発されたシステムは，まず対象化し，その 安定性を実験計画法により分析，確認した。

次に幅員 $600 \mathrm{~m}$ の航路の交通容量を分析し，時間当 り40 隻という值を得た。また, 主航路交通量を 24 (隻 /時間)とした時の交差航路の容量として，10(隻/時間) を得た。

瀬戸内海航路の現状での船舶交通量をみてみると，幅 員 $400 \mathrm{~m}$ の来島中水道, 幅員 $700 \mathrm{~m}$ の備讃瀬戸北水道 では，ピーク時における通航船舶は，おのおの約 30 隻/ 時間，20 隻/時間 となっている。したがってこれらの 值と現状での航路の実感的混雑感とを対比すれば，上述 の容量はかなり妥当なものといえる。

6.（2）の分析でも指摘したように，群の発生は，航 路幅員と船種,船型構成により異なる。この群の発生は, 船舶交通流の分析において非常に重要なものといえる。 また図一11で指摘したように, 到着パターンによって， システムの応答状態が異なり，その容量も変化する。

このように, 航路交通容量の概念化には, 種々の問題 があることは明らかであろう。特に，

(1) 航路固有の特性としての到着パターン, 船種, 船 型構成等の標示要因の標準化

(2) 群の発生に伴う“車線”概念の変更 および

(3) 外的基準の操作的定義とその経験的妥当性の検討 は重要な課題といえる。

また，分析過程を通じて，われわれは瀬戸内海地域の 開発構想を航路交通容量の側面より再検討することの必 要性を強く感じたことを報告しておく。

最後に，本研究に全面的な協力と援助をいただいた運 輸省第三港湾建設局の各位と, 船舶交通の特 異 性につ
き, 有益な示唆をいただいた神戸商船大学 山口 篤教 授, 松木 哲助教授, 浜畑勇技官, さらに本論文作成に 当り，終始ご指導いただきました京都大学 吉川和広教 授を始め研究室の各員に感謝の意を表します。

\section{参 考 文 献}

1）スコット・グリア（奥田・大坪訳）：「現代都仴の危機創 造」, 鹿島出版会（昭 45）

2) D.R.J. Tinbergen : $\lceil$ Project Criteria

3) 藤井弥平・田中健一：「海上:交通工学序説」,船舶 Vol. 42 , No. $7 \sim 10$

4）運輸省第三港湾建設局：「来鼠海峡通航船舶航跡淍查報告 書」, 昭 42 年 12 月

5）運輸省第三港湾建設局：「借潜瀬戸通航船航跡阔査報告 書 $j$, 昭 43 年 3 月

6）運輸省第四港湾建設局：「関門航路におりる通航船舶調査 報告書」, 昭 43 年 3 月

7）藤井弥平 他: “船舶の閉塞領域について”, 日本航海学 会誌, 昭 41 年 7 月

8）谷 初蔵：“Crash-Astern 操作の停止距離におよぼす船 の旋回の影響”, 日本航海学会誌, 昭 40 年 7 月

9）原潔：“船舶交通の統什的特性一I”，日本航海学会 誌, 炤 41 年 7 月

10) A.V. Gafarian and C.J. Ancker : "Mean Value Estimation from Digital Computer Simulation", M.S, Vol. 15, 1965

11) Thomas, H. Naylor and J.M. Finger : "Verification of Computer Simulation Models", M.S Vol. 14 No. 2, 1967.

12）宮川公男：「PPBS の原理と分析」，有斐閣，炤和 44 年 11 月

13）長尾義三 :「港湾工学」, 共立出版, 昭 44 年 5 月

14）運輸省第四港湾建設局：「関門航路における船舶交通容量 に関する研究一交通容量におよぽす潮流の影響について 一」, 昭 43 年 3 月

15）運輸省第三港湾建設局：「瀬戸内海航路の余裕水深と航路 幅員に関する調査報告書」, 昭 39 年 3 月

16）山口篤利・黑田 隆：“狭水路における操船者の緊張感”, 日本航海学会誌, 昭 40 年 12 月

17) Martin K. Starr : “Planning Models", M.S Vol. 13 No. 4, 1966

18）オスカー・ランゲ(鶴岡重成訳)：「システムの一般理論」, 合同出版, 昭 44 年 8 月

19) T. Hermanson : "Information System for regional development control”, Regional Science Association papers XXI 1969

(1970.9.7 · 受付) 